\title{
O espaço da Utopia: impulso utópico e mapeamento cognitivo em TAZ - Zona Autônoma Temporária
}

\author{
Marcelo Cizaurre Guirau*
}

\begin{abstract}
Resumo
Nesse estudo, propomos uma leitura do livro TAZ, escrito por Hakim Bey, à luz da noção de "impulso utópico" (nossas referências aqui são Ernst Bloch e Fredric Jameson) e do conceito de "mapeamento cognitivo", desenvolvido por Jameson. A nossa análise mostrará que $T A Z$, enquanto construção utópica, apresenta uma série de lacunas e inconsistências, as quais orientarão nosso esforço cognitivo, uma vez que serão lidas como "sintomas instrutivos" da atual crise da imaginação histórica.
\end{abstract}

\section{Palavras-chave}

TAZ. Impulso utópico. Mapeamento cognitivo. Utopia.

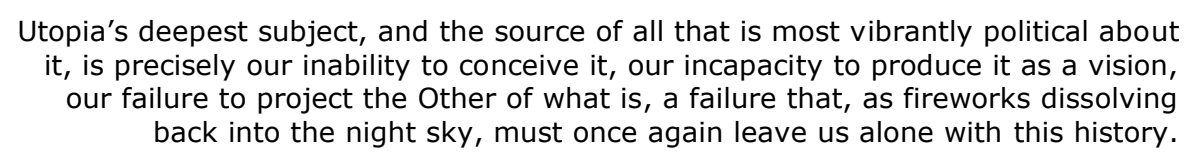
Jameson (1988, p. 101)

\section{Um desejo chamado Utopia}

TAZ é definida por seu autor como "um ensaio ('uma tentativa'), uma sugestão, quase que uma fantasia poética." (BEY, 2004, p. 14). O caráter provisório e tateante do ensaio como forma (Cf. ADORNO, 1986) concede a liberdade formal necessária para o esforço de conceituação que inspira essa obra, a qual evoca, para sua construção, o poder "legitimador" do discurso acadêmico e a liberdade de criação do texto literário.

Texto misto, deliberadamente impuro, TAZ é, sobretudo, um texto Utópico ${ }^{1}$, que tenta dar forma a um desejo ("O desejo chamado Utopia") e enfrenta as dificuldades

\footnotetext{
* Doutorando em Estudos Linguísticos e Literários em Inglês pela Universidade de São Paulo. Bolsista da CNPQ. Docente do Centro Universitário Ítalo Brasileiro. Email: cizaurre@hotmail.com.
} 
de se pensar alternativas numa situação histórica em que elas parecem ter desaparecido. 0 registro ${ }^{2}$ desse enfrentamento fica impresso nas lacunas e indecisões da construção Utópica, uma vez que

\begin{abstract}
Nem sempre os desejos podem ser fantasiados com sucesso: tal é o resultado dos limites tanto da narrativa quanto do Real. Da mesma forma, nem sempre se pode realizar uma construção: há limites de material e de situação histórica que funcionam como estática e dinâmica, as leis elementares da gravidade e da locomoção, e da construção de coletivos imaginários. (JAMESON, 2004, p. 269).
\end{abstract}

Menos do que um projeto político, TAZ é um experimento de imaginação utópica. Ao final da leitura, não se sabe exatamente o que é a TAZ e onde localizá-la. Não se pode ao menos defini-la com um mínimo de clareza. Enquanto ideia, ela impõe à mente um embaraço epistemológico semelhante àquele de Santo Agostinho diante da tarefa de definir o que é o tempo: "O que é, por conseguinte, o tempo? Se ninguém me perguntar, eu sei; se o quiser explicar a quem me fizer a pergunta, já não sei." (AGOSTINHO, 1996, p. 322). Para Hakim Bey, "No final, a TAZ é quase autoexplicativa. Se o termo entrasse em uso seria compreendido sem dificuldades... compreendido em ação." (BEY, 2004, p. 14).

Se TAZ não tem valor de orientação política, se não oferece estratégias para a ação política imediata, o que resta de interesse nessa obra? Em um mundo em que as alternativas ao atual modo de produção parecem ter desaparecido, enterradas sob os escombros da História (que, para Francis Fukuyama e seus seguidores chegou ao fim), a imaginação utópica assume o papel de manter o futuro vivo, de mantê-lo aberto à possibilidade de mudança. Experimentos de imaginação utópica como TAZ encerram um gesto de resistência contra o perigo da destruição do futuro, descrito assim por Fredric Jameson:

\begin{abstract}
Where Benjamin observed that "not even the past will be safe" from conquerors, we may now add that the future is not safe either, and that it is compared to that leveling of the land speculators and builder-investors, whose bulldozers destroy all site-specific properties of a terrain in order to clear it and make it fungible for any kind of future investment, so that one can build on it whatever the market demands. This is the future prepared by the elimination of historicity, its neutralization by way of progress and technological evolution [...] (JAMESON, 2005, p. 228).
\end{abstract}

\title{
2. Rastreando o impulso utópico
}

Boa parte do livro de Hakim Bey ${ }^{3}$ é dedicada ao inventário de "enclaves" utópicos que possam ser descritos como Zonas Autônomas Temporárias.

\footnotetext{
${ }^{1}$ Sobre a Utopia como assunto político e forma literária, ver a introdução do livro Archaeologies of the Future: The Desire Called Utopia and other Science Fictions, de Fredric Jameson.

2 "What is productive about the Utopian text can on this view best be grasped if we take it to be a registering apparatus for detecting the feeblest positive signals from the past and the future and for bricolating and combining them and thereby producing what looks like a representational picture." (JAMESON, 2005, p. 29).

3 Especialmente os capítulos 1 (Utopias Piratas), 5 ("Fomos para Croatã") e 6 (A Música como um Princípio Organizacional).
} 
Ao mesmo tempo em que o autor busca nessas experiências reais de "autonomia" sustentação empírica para a tese da existência da TAZ, elas servem também a uma função "estética", substituindo a criação de um novo mundo (a TAZ nunca é espacialmente descrita) pela evocação de espaços reais em que se registrou uma experiência de autonomia como concebido pelo conceito de TAZ.

Assim, esses espaços saciam a imaginação com o vislumbre de comunidades que vivem "'utopias' criadas quase ex nihilo in terra incognita, enclaves da total liberdade ocupando espaços vazios do mapa." (BEY, 2004, p. 48). A simples criação abstrata do conceito de TAZ parece insuficiente para insuflar impulso utópico nessa ideia de Zonas Autônomas Temporárias. A presença de espaços como as ilhas de Barbados e Jamaica, a comunidade de Croatã, as "comunidades isoladas tri-raciais, as comunas revolucionárias urbanas da Europa, a República de Fiúme, Libertatia (ficcional) etc... cria um apoio perceptivo para a ideia de TAZ.

Guardadas as devidas proporções, podemos dizer que nesse pequeno livro há um esforço de inventariar formas de manifestação da Utopia que lembra a construção do vasto edifício da imaginação utópica empreendida por Ernst Bloch em "O Princípio Esperança".

Em seu livro, Bloch insiste na necessidade de se criar uma "hermenêutica da esperança", uma "ciência" do desejo utópico que possibilite a mediação entre o impulso utópico e a existência cotidiana de maneira a construir, a partir da aproximação crítica do desejo, caminhos para sua realização:

\begin{abstract}
Anseio, expectativa e esperança necessitam, portanto, de sua hermenêutica, a aurora do que está diante de nós exige seu conceito específico, o novum requer o seu conceito avançado. E tudo isto com a finalidade de que, pelo reino da possibilidade assim mediado, finalmente se construa, com olhar crítico, a estrada que leva ao que necessariamente se busca, e que ela seja mantida sempre nessa direção. Docta spes, a "esperança compreendida", torna claro assim o conceito de um princípio que não mais deixa o mundo. (BLOCH, 2005, p. 17).
\end{abstract}

A TAZ é, nos parece, uma tentativa de tal ordem. Seu conteúdo utópico consiste na intenção de dar forma a uma maneira de viver qualitativamente distinta da atual. Ainda que TAZ falhe como criação ontológica, pois não consegue propor um universo de relações que fuja definitivamente da determinação ${ }^{4}$ (o "Temporário" do título é indício dessa falha), a ideia de Zonas Autônomas expressa, mesmo que de forma distorcida, um desejo de mudança latente sob a superfície do cotidiano. TAZ é uma expressão de uma "estrutura de sentimento" ${ }^{5}$ da ruptura, de uma recusa do mundo capitalista, da necessidade de rompimento com a ordem atual.

\footnotetext{
4 "A construção de uma sociedade livre pressupõe uma ruptura com a experiência familiar do mundo - com uma sensibilidade mutilada. Condicionada e 'contida' pela racionalidade do sistema estabelecido, a experiência dos sentidos tende a 'imunizar' o homem contra a experiência insólita das possibilidades de liberdade humana". (MARCUSE, 1981, p. 66). Em TAZ, vemos a proposta de substituição de categorias de organização social atualmente em vigor por outras também existentes no mundo atual, ainda que não hegemônicas. Não há invenção de categorias que busquem uma ruptura com a lógica do capitalismo.

${ }^{5}$ Conceito criado por Raymond Williams.
} 


\section{A necessidade de mapas}

TAZ é uma formulação espacial marcada pelo paradoxo: é uma zona (espaço) ${ }^{6}$, mas sua existência depende de sua não-fixação em lugar algum: "A TAZ possui uma localização temporária mas real no tempo, e uma localização temporária mas real no espaço... a TAZ é um acampamento nômade." (BEY, 2004, p. 33).

A arquitetura líquida de TAZ encontra na Internet o meio ideal para seu nomadismo. Mas a escolha pelo espaço virtual amplia o paradoxo espacial de TAZ: como conciliar a existência de uma zona autônoma real no espaço e no tempo que dependa do mundo virtual para existir? Esse dilema espacial da TAZ é tratado da seguinte maneira:

A TAZ deseja, acima de tudo, evitar a mediação, experimentar a existência de forma imediata. A essência da TAZ é "peito-a-peito", como dizem os sufis, ou caraa-cara. Mas, MAS: a essência da web é mediação, onde as máquinas são nossos embaixadores - a carne é irrelevante exceto como um terminal, com todas as conotações sinistras do termo.

Talvez a melhor maneira para a TAZ encontrar seu próprio espaço seja adotando duas atitudes aparentemente contraditórias em relação à alta tecnologia e sua apoteose, a net: a) aquilo que podemos chamar de Quinto Estado, a posição neopaleolítica, pós-situacionista e ultra-verde, que se traduz como um argumento ludita contra a mediação e contra a internet; e b) os cyberpunks utópicos, os futuro-libertários, os hackers da realidade e seus aliados, que percebem a internet como um passo adiante na nossa evolução, e que acreditam que qualquer possível efeito maligno da mediação possa ser superado, ao menos depois de termos liberado os meios de produção.

A TAZ concorda com os hackers porque deseja em parte - ganhar existência através da net, e até mesmo através da mediação da net. Mas ela também concorda com os partidários do ambientalismo porque possui uma intensa percepção de si mesma como corpo e sente nojo da cibergnose, a tentativa de transcender o corpo através da instantaneidade e da simulação. (BEY, 2004, p. 34$5)$.

A contradição apontada fica suspensa, a espera de resolução. Aqui, a dialética trava diante da dificuldade imposta pela crescente abstração que domina a experiência hoje. Fredric Jameson descreve assim esse problema:

Tudo isso, como sugerido acima, atinge intensidade máxima no nosso período como resultado da "revolução" cibernética, a expansão das tecnologias de comunicação ao ponto em que as transferências de capital abolem hoje tempo e espaço e podem ser efetuadas de forma virtualmente instantânea entre as diferentes zonas nacionais. Os resultados desses movimentos instantâneos de imensas quantidades de dinheiro em torno do globo são incalculáveis, e no entanto já produziram claramente novos tipos de bloqueio político e também sintomas novos e irrepresentáveis na vida quotidiana do capitalismo tardio. Pois o problema da abstração - de que o do capitalismo financeiro é parte - deve também ser compreendido em suas expressões culturais. (JAMESON, 2001, p. 151).

\footnotetext{
6 "A TAZ é um lugar físico, no qual estamos ou não estamos. Todos os sentidos estão, necessariamente, presentes." (BEY, 2004, p. 72). "A TAZ é 'utópica' no sentido que imagina uma intensificação da vida cotidiana ou, como diriam os surrealistas, a penetração do Maravilhoso na vida. Mas não pode ser utópica no sentido literal do termo, sem local, ou 'lugar do lugar nenhum'." (BEY, 2004, p. 35).
} 
O problema da busca de "Zonas Autônomas" passa pelo problema maior de se conceber uma totalidade a partir da qual a autonomia deve ser busca. Esse é o problema da representação estética e do mapeamento cognitivo pressuposto do projeto de análise espacial da cultura empreendido pelo crítico cultural Fredric Jameson: "The project of cognitive mapping obviously stands or falls with the concept of some (unrepresentable, imaginary) global social totality that was to have been mapped." (JAMESON, 2000, p. 286).

Em TAZ observamos a presença espectral de uma força onipotente $e$ onipresente, contra a qual não é possível lutar, só restando a fuga e a invisibilidade como possibilidades de liberdade:

\begin{abstract}
Absolutamente nada, além do martírio inútil, poderia resultar de um confronto direto com o Estado terminal, esta megacorporação/Estado de informações, o império do Espetáculo e da Simulação. Todos os seus revólveres estão apontados para nós. Por outro lado, com nosso armamento miserável, não temos em que atirar, a não ser numa histerese, num vazio rígido, num fantasma capaz de transformar todo lampejo num ectoplasma de informação, uma sociedade de capitulação regida pela imagem do policial e pelo olho absorvente da tela de TV. (BEY, 2004, p. 17).
\end{abstract}

As TAZ surgem nas rachaduras e fendas que existem nesse universo de controle quase total (BEY, 2004, p. 18). Não seria possível pensá-las a partir de um universo em que o controle fosse absoluto. Mesmo as visões mais pessimistas do quadro atual de expansão do capital guardam espaços, ainda que mínimos, para que uma ruptura possa ser imaginada (o "princípio esperança" de Bloch em ação!). Podemos encontrar essas concepções de uma "falha no sistema" até mesmo na "ironia hiper-conformista" (BEY, 2004, p. 68) de Baudrillard:

Quando mais hegemônico é um sistema, tanto mais a imaginação é atingida pelo
seu menor revés. O desafio, mesmo infinitesimal, é a imagem de uma falha em
cadeia. Só esta reversibilidade sem medida comum constitui um acontecimento
político. Só ela mobiliza o imaginário. (BAUDRILLARD, 2991, p. 200).

TAZ é um espaço utópico porque se constitui como um enclave de descontinuidade em relação à hegemonia do "Estado"7 . A definição de "espaço utópico" dada por Fredric Jameson ajuda-nos a entender TAZ como um experimento de imaginação utópica: "Utopian space is an imaginary enclave within real social space, in other words, that the very possibility of Utopian space is itself a result of spatial and social differentiation." (JAMESON, 2005, p. 15).

A necessidade de buscar essa "diferenciação social e espacial" motiva um exercício de mapeamento cognitivo que, em TAZ, aparece na forma de uma proposta de mapeamento das zonas cegas à onipresença do "Estado", a partir das quais podem eclodir (para depois desaparecer) as TAZ. O que propõe é um experimento de "cartografia psíquica", que busque criar um mapa da autonomia possível:

\footnotetext{
7 Estado é a palavra de Bey usa para se referir ao "sistema". Em TAZ, ela possui uma conotação
} além da política. 
O mapa está fechado, mas a zona autônoma está aberta. Metaforicamente, ela se desdobra por dentro das dimensões fractais invisíveis à cartografia do Controle. E aqui podemos apresentar o conceito de psicotopologia (e psicotopografia) como uma "ciência" da alternativa àquela da pesquisa e criação de mapas e "imperialismo psíquico" do Estado. Apenas a psicotopografia é capaz de desenhar mapas da realidade em escala $1: 1$, porque apenas a mente humana tem a complexidade suficiente para modelar o real. (BEY, 2001, p. 22).

Podemos antever uma geografia completamente nova, um tipo de mapa de peregrinação no qual os lugares sagrados são substituídos por experiências de pico e TAZ: uma ciência real de psicotopografia, para ser chamada talvez de "geoautonomia" ou "anarcomancia." (BEY, 2001, 73).

A preocupação com mapas é visível em TAZ. A necessidade de mapear é um pressuposto da criação de espaços utópicos, uma vez que esse espaço é imaginado em relação a uma base ontológica determinada. Arriscamos, assim, afirmar que o trabalho de mapear uma totalidade (seja ela imaginada ou dada) é um imperativo da construção de utopias.

A ideia de uma "psicotopografia" nos parece uma tentativa de formular uma cartografia que inclua a agência como força motriz. No entanto, a proposta de um mapeamento feito a partir do sujeito aponta para um limite de imaginação histórica diante qual o pensamento trava: como pensar uma ruptura ontológica que parta de um elemento (a mente, o sujeito) imerso no universo de determinações do qual ele pretende escapar? Aqui se tem uma aporia ilustrada por Walter Benjamin na imagem de uma pessoa que, presa da areia movediça, tentar sair de lá puxando o próprio cabelo. A saída só é possível numa dimensão maior que a do sujeito, a saber, o coletivo. O fato de TAZ mergulhar na aporia acima mencionada só testemunha a dificuldade de se pensar alternativas fundadas não no indivíduo, mas numa coletividade. Mesmo a figura da TAZ não é muito bem trabalhada como um projeto coletivo e sim como uma solução provisória para indivíduos.

O "problema da abstração" de que fala Jameson é perceptível nesse empenho de mapear algo que não se fixa:

Se fôssemos imaginar um mapa da informação uma projeção cartográfica da net como um todo - teríamos que incluir os elementos do caos que já começaram a aparecer, por exemplo, nas operações de processos paralelos complexos, nas telecomunicações, na transferência de "dinheiro" eletrônico, nos vírus, na guerrilha dos hackers etc.

Cada uma dessas "áreas" de caos poderiam ser representadas por topografias semelhantes às do Mandelbrot Set, de forma que as "penínsulas" ficassem embutidas ou escondidas dentro do mapa e quase "desaparecessem". Esta "escrita" - que em parte desaparece e em parte se esconde - representa o próprio processo que já é parte intrínseca da net, não totalmente visível nem para si mesmo, inControlável. (BEY, 2004, 37).

A quantidade de palavras entre aspas nesse pequeno trecho de TAZ dá a medida da hesitação de um pensamento de caminha em solo instável. 


\title{
4. O problema: como localizar a diferença radical?
}

Vimos como TAZ codifica um impulso utópico pela ruptura. Vimos, também, como esse texto é um esforço de mapeamento cognitivo. As lacunas e inconsistências apontadas na construção utópica e na tentativa de mapeamento são menos defeitos do texto que sintomas da dificuldade de se imaginar alternativas para romper com o capitalismo. Assim, TAZ é um "sintoma instrutivo" (BAUDRILLARD, 2003) de alguns dos dilemas mais significativos do pensamento crítico atual.

Ler esse tipo de texto exige uma atitude crítica que não se deixe seduzir pela fluidez dos significados, mas que busque apoio na solidez da História, horizonte último de interpretação.

Exemplar desse tipo de atitude é a interpretação de Fredric Jameson do conceito de Junkspace, formulado pelo arquiteto Rem Koolhaas. Enquanto formulação espacial, Junkspace opta pela fluidez e pela indefinição:

\begin{abstract}
Junkspace is a Bermuda triangle of concepts, a petri dish abandoned: it cancels distinctions, undermines resolve, confuses intention with realization. It replaces hierarchy with accumulation, composition with addition. More and more, more is more. Junkspace is overripe and undernourishing at the same time, a colossal security blanket that covers the earth in a stranglehold of care... Junkspace is like being condemned to a perpetual Jacuzzi with millions of your best friends... A fuzzy empire of blur, it fuses high and low, public and private, straight and bent, bloated and starved to offer a seamless patchwork of the permanently disjointed. (KOOLHAAS, 2002).
\end{abstract}

A resposta crítica de Jameson a esse objeto de difícil cognição é paradigmática:

\begin{abstract}
The problem is then how to locate radical difference; how to jumpstart the sense of history so that it begins again to transmit feeble signals of time, of otherness, of change, of Utopia. The problem to be solved is that of breaking out of the windless present of the postmodern back into real historical time, and a history made by human beings. I think this writing is a way of doing that or at least of trying to. Its science-fictionality derives from the secret method of this genre: which in the absence of a future focuses on a single baleful tendency, one that it expands and expands until the tendency itself becomes apocalyptic and explodes the world in which we are trapped into innumerable shards and atoms. The dystopian appearance is thus only the sharp edge inserted into the seamless Moebius strip of late capitalism, the punctum or perceptual obsession that sees one thread, any thread, through to its predictable end. (JAMESON, 2003, p. 9).
\end{abstract}

TAZ é um texto que merece esse tipo de atenção crítica. O espaço desse artigo não nos permite um engajamento mais criticamente produtivo com tal tarefa. Esperamos, no entanto, ter, com essa breve exposição, indicado alguns pontos de interesse crítico que possam ajudar em futuras tentativas de leitura dessa obra.

\section{Referências}

ADORNO, Theodor. O ensaio como forma. In: COHN, Gabriel. Theodor Adorno. São Paulo: Ática, 1986. 
AGOSTINHO, Santo. Confissões. Tradução de J. Oliveira Santos e Ambrósio de Pina. São Paulo: Nova Cultural, 1996. Coleção Os Pensadores

BAUDRILLARD, Jean. Simulacros e Simulação. Lisboa: Relógio d'água, 1991.

. Baudrlillard decode Matrix. Le Nouvel Observateur, n. 19, jun. 2003.

BEY, Hakim. TAZ - Zona Autônoma Temporária. São Paulo: Conrad, 2004.

BLOCH, Ernst. O princípio esperança. Trad. de Nélio Schneider. Rio de Janeiro: Ed. UERJ; Contraponto, 2005. V1.

JAMESON, Fredric. Archaeologies of the future: the desire called utopia and other science fictions. London, Verso, 2005.

. A cultura do dinheiro. Petrópolis: Vozes, 2001.

. Cognitive mapping. In: HARDT, Michael; WEEKS, Kathi (eds.) The Jameson

Reader. Oxford: Blackwell, 2000.

. Espaço e imagem (teorias do pós-moderno e outros ensaios). Rio de

Janeiro: Editora UERJ, 2004.

. Future city. New left review, maio/jun. 2003. Disponível em:

<http://newleftreview.org/A2449>. Acesso em: 17 nov. 2009.

Of islands and trenches: neutralization and the production of utopian

discourse. Ideologies of Theory 2, Minneapolis, University of Minnesota Press, 1988.

KOOLHAAS, Rem. Junkspace, Oct., Vol. 100, Obsolescence (Spring, 2002), p. 175-

190. Disponível em: <http://www.jstor.org/pss/779098>. Acesso em: 17 nov. 2009.

MARCUSE, Herbert. Contra revolução e revolta. Rio de Janeiro: Zahar, 1981.

\section{Title}

The space of Utopia: utopian impulse and cognitive mapping in TAZ - Temporary Autonomous Zone

\section{Abstract}

In this work, we offer a reading of the book TAZ, written by Hakim Bey, according to the notion of "utopian impulse" (our reference here will be Ernst Bloch and Fredric Jameson) and to the concept of "cognitive mapping", which have been worked by Jameson. Our analyses will show that TAZ, as an utopian construction, show some lacunas and inconsistencies which will guide our cognitive effort due to the fact that they will be read as "instructive symptoms" of the present crisis of the historical imagination.

\section{Keywords}

TAZ. Utopian impulse. Cognitive mapping. Utopia.

Recebido em 2/01/2012. Aprovado em 20/10/2012. 


\title{
Invenção de Orfeu, Jorge de Lima em busca da idade de ouro
}

\author{
Luciano Marcos Dias Cavalcanti*
}

\section{Resumo}

Este texto pretende examinar como Jorge de Lima em Invenção de Orfeu, em uma investida mítico-poética, busca restaurar a idade de ouro em seu poema. Nesse sentido, estudaremos autores exemplares da tradição literária ocidental que trabalharam este tema no intuito de estabelecermos um possível diálogo do poeta alagoano com esta tradição.

\section{Palavras-chave}

Invenção de Orfeu. Mito. Poesia. Idade de ouro

A época áurea para a quase totalidade das mitologias se deu no princípio dos tempos. ${ }^{1}$ Neste momento, o homem desfrutava de uma felicidade total e vivia em plena harmonia com os deuses e com a natureza. A concepção da bem-aventurança e da perfeição está principalmente vinculada à ideia da "origem", mas há também, na concepção escatológica, entendida como uma criação do futuro. Nesse sentido, após a destruição do mundo, seguida da criação de um novo mundo, encontramos a idealização de uma nova Idade de Ouro, não somente no passado, mas também no futuro. Esta perspectiva é exemplarmente representada pela teologia cristã, que acredita que no fim dos tempos o paraíso será recuperado, conforme se pode ver no Apocalipse XXI, 1-5.

Historicamente, o mito da perfeição do início dos tempos na tradição clássica ocidental inicia-se com Hesíodo (com a Raça de Ouro) que ele narra em Os trabalhos e os dias. Nas cinco raças criadas pelos deuses (a de ouro, prata, bronze, heróis e a de ferro) a trajetória humana é contada desde sua perfeição à sua decadência, onde se encontra o homem no presente, a Raça de Ferro. Hesíodo, já nos seus primeiros versos apresenta seu enorme desgosto por pertencer a ela: "Antes não estivesse eu entre os homens da quinta raça,/mais cedo tivesse morrido ou nascido depois./Pois agora é a raça de ferro e nunca durante o dia/cessarão de labutar e penar e nem à noite de se/destruir; e árduas angústias os deuses lhe darão." Contrariando todo esse pesar, Hesíodo descreve a Raça de Ouro:

\footnotetext{
* Doutor em Teoria e História Literária pelo IEL-UNICAMP e Pós-doutorando em Literatura Brasileira UNESP-Araraquara.

${ }^{1}$ Este texto é parte integrante da pesquisa de Pós-doutorado, em andamento, denominada "Mito e poesia em Invenção de Orfeu de Jorge de Lima", junto ao Departamento de Literatura/UNESP-Araraquara financiada pela FAPESP
} 
Se queres, com outra estória esta enimarei;

bem e sabiamente lança-a em teu peito!

[Como da mesma origem nasceram deuses e homens.]

Primeiro de ouro a raça dos homens mortais

criaram os imortais, que mantêm olímpias moradas.

Eram do tempo de Cronos, quando no céu este reinava;

como deuses viviam, tendo despreocupado coração,

apartados, longe de penas e misérias; nem temível

velhice Ihes pesava, sempre iguais nos pés e nas mãos,

alegravam-se em festins, os males todos afastados,

morriam como por sono tomados; todos os bens eram

para ele: espontânea a terra nutriz fruto

trazia abundante e generoso e eles, contentos,

tranquilos nutriam-se de seus próprios bens.

Mas depois que a terra a esta raça cobriu

eles são, por desígnios do poderoso Zeus, gênios

corajosos, ctônicos, curadores dos homens mortais.

[Eles então vigiam decisões e obras malsãs,

Vestidos de ar vagam onipresentes pela terra.]

E dão riquezas: foi este o seu privilégio real.

Mary de Camargo Neves Lafer, tradutora desta obra, considera dois pontos importantes para o esclarecimento das raças inventadas por Hesíodo: a humanização das raças relativa às idades humanas e a circularidade do tempo.

\begin{abstract}
Primeiro, as raças de ouro e de prata não têm nenhum conhecimento da necessidade, tudo lhes é dado espontaneamente, vivem sem preocupações, achamse, assim, ligadas à infância, conforme já havia observado West. Já as raças de bronze e dos heróis se vincularam ao vigor físico próprio da idade adulta. A raça de ferro é a única que conhece a degradação da infância para a velhice e a morte. Em segundo lugar, observamos que o tempo do mito não é linear e sim cíclico, assim como o é a sequência das estações do ano - se assim não fosse estaria completamente deslocada a raça dos heróis, que não segue seu paralelismo raçametal; por outro lado, ainda, Hesíodo declarando claramente que gostaria de já estar morto antes da raça de ferro ou nascer depois dela, fica evidente não o término de um processo de declínio mas a existência de uma continuidade cíclica. (LAFER, 1996, p. 87).
\end{abstract}

Desse modo, pela deteriorização contínua da primeira à quinta raça, já na quarta raça introduz uma descontinuidade nesta decadência, o que se pode supor a criação de uma raça melhor posterior a raça de ferro, pois lamenta Hesíodo "ter morrido muito tarde", ou "ter nascido muito cedo". Portanto, mais que um declínio contínuo, fala-se, em Os trabalhos e os dias, de um retorno a raça de ouro.

Ovídio e Virgílio também vão criar suas idades de ouro trazendo ainda mais popularidade a este mito, difundido durante o passar dos séculos pelas narrativas de viagem, de relatos fabulosos, pelos poemas, etc., demonstrando o fascínio que o 
homem sempre teve pela perfeição do início dos tempos e sua busca nostálgica dessa época ${ }^{2}$.

Em Ovídio, a idade de ouro está presente no Livro I das Metamorfoses. Neste poeta, a visão do mundo perfeito é semelhante ao significado corrente do mito: lugar de perfeição onde o homem vivia plenamente em harmonia com a natureza, sem dor, medos ou guerras, sem nenhum trabalho - a terra produzia seus frutos, a primavera era eterna, o leite e o mel eram acessíveis e estavam em toda parte.

Foi a primeira idade a idade de ouro:

Sem nenhum vingador, sem lei nenhuma

Culto à fé, e à justiça então se dava,

Ignoravam-se então castigo, e medo;

Ameaços terríveis se não liam

No bronze abertos; súplice caterva

À face do juiz não palpitava:

Todos viviam sem juiz, sem dano.

Inda nos pátrios momentos decepado

Às ondas não baixava o pinho ingente

Para depois ir ver um mundo estranho:

De mais clima que o seu ninguém sabia.

Fossos ainda não cingiam muros,

As tubas, os clarins não ressoavam,

Nem armas, nem exércitos havia:

Sem eles os mortais de paz segura

Em ócios inocentes se gozavam.

O ferro sulcador não a rompia,

E dava tudo a voluntária terra.

Contente do que brota sem cultura

Colhia a gente o montanhês morango,

Crespo medronhos, e as cerejas bravas,

Às duras silvas as amoras presas,

E as lisas produções de tênue casca,

Que da árvore de Júpiter caíam.

Eram todas as quadras primavera.

Mansos Favônios com sutil bafejo,

Com tépidos suspiros animavam

As flores, que sem germe então nasciam.

\footnotetext{
2 Ribeiro caracteriza bem o significado simbólico que a época áurea tem para nós: "Na verdade, por maior que seja o avanço do conhecimento, o homem parece incapaz de aceitar como inelutável a idéia de que sua existência seja vazia de sentido. Afinal, a que poderia levar uma tal capitulação? Eis porque não seria descabido pensar que a obsessão pela "perfeição dos começos" reveste-se de características ontológicas. Não se pode dissociá-la da situação do homem de "ser-aí", de "ser-no-mundo", ignorando o "como", o "por que" e o "para quê" veio, perplexo diante da realidade da degradação, do sofrimento e sobretudo da morte; de ser-nomundo que, se por meio da razão busca desesperadamente a Verdade, alcança pela fantasia essa verdade como "ficção", como "ilusão", como "mito", que muitas vezes para ele tem o valor da verdade mais autêntica, pois é verdade "sagrada", revelada pelos Entes Sobrenaturais in illo tempore. Assim, o mito da idade de ouro é, talvez, aquele que mais intimamente se associa à vida da humanidade, manifestando-se em todas as formas de expressão de que é capaz, revestindo aqueles significados que refletem com mais propriedade a força da sua razão, da sua imaginação e do seu imorredouro otimismo." (RIBEIRO, 1986, p. 23, grifos do autor).
} 
Viam-se enlourecer, vingar as messes

Nos campos nem roçados de adubio,

Em rios ir correndo o leite, o néctar;

E da verde azinheira estar caindo

O flavo mel em pegajosas gotas.

No caso específico de Ovídio, o topos do lugar ideal traz uma característica singular que nos interessa de perto, pois é onde a obra poética de Jorge de Lima se desaguará, em Invenção de Orfeu. Poema em que o mito de Orfeu terá lugar privilegiado. Nesse ambiente paradisíaco, a presença de Orfeu é marcante, pois é através de seu canto que o locus amoenus aparece. Nesse sentido, sua presença é imprescindível; caso contrário, o lugar paradisíaco não existiria. Curtius assinala que

Ovídio aproveita o tema da "floresta mista" para engenhosas variações: em vez de aparecer logo de início, o bosque vai surgindo gradualmente diante de nossos olhos. Vemos primeiro uma colina inteiramente desprovida de sombra. Sai então Orfeu dos bastidores e começa a tanger as cordas de sua lira. E logo as árvores ocorrem - nada menos de vinte e seis e espécies! - a oferecer suas sombras. (Met.; 10, 90-106). (CURTIUS, 1996, p. 253).

Desse modo, o mito da idade de ouro pode ser associado ao mito órfico a despeito de que Orfeu com seu canto possibilitaria o sonho da comunhão dos homens com a natureza, estabelecendo um ambiente análogo ao lócus amoenus, onde existiria uma relação harmônica entre homem e natureza.

Em Virgílio, a idade áurea está presente na sua IV Bucólica, onde o poeta anuncia o nascimento de uma criança que trará de volta a idade de ouro. É interessante notar que tanto em Hesíodo quanto em Virgílio a idade de ouro está diretamente associada à infância. Neste último, é clara a similitude com o nascimento de Cristo, associando, assim, o mito ao pensamento cristão ${ }^{3}$.

A última idade já chegou da predição de Cumas:

a grande ordem dos séculos, de novo ei-la que nasce.

Também já volta a Virgem, volta o reino de Saturno;

Já uma nova progênie desce dos mais altos céus.

Casta Lucina, ampara, que já reina o teu Apolo,

O menino que está nascendo: a geração de ferro

com ele findará, ao mundo vindo a raça de ouro. (Virgílio IV, "Pólio", vs. 4-10)

Há também na mitologia da idade de ouro a ideia que o paraíso terrestre ainda existe na terra, mas ele está muito bem escondido. Este tipo de concepção aparece desde a Antiguidade e vai até a Idade Média e a Renascença, e sua principal concepção está na lenda das Ilhas Afortunadas. Local distante e/ou perdido do mundo conhecido, lugar que diferentemente das mitologias comentadas anteriormente, pode ser encontrado, está ao alcance dos homens.

${ }^{3}$ É exemplar a fama que As Bucólicas alcançaram na Idade Média, principalmente a quarta delas. De acordo com Péricles Eugênio da Silva Ramos, "tomou-se, naquele tempo, o menino que iria nascer, junto com uma nova idade de ouro no mundo, como o próprio Cristo, ganhando Virgílio a dignidade de profeta." (In: Introdução As Bucólicas, 1982, p. 7). 
Na Idade Média, uma das presenças mais marcantes da idade de ouro foi representada pela viagem de São Brandão em busca do Paraíso. Essa narrativa do século IX foi retomada em variadas versões em contos e poemas. No texto de São Brandão sua forma visual é admirável:

\begin{abstract}
Em todos os lugares para onde nossos olhos se voltam, o que se vê são bosques espessos, árvores de frondosas copas, carregadas de frutos que luzem magnificamente, de flores inigualáveis, que misturam seus perfumes suaves e penetrantes; são regatos saltitantes de águas cristalinas; são regatos de leite que serpenteiam no meio dos prados de gramado macio. Em toda parte, grande quantidade de animais vive a folgar: o cervo convive com o lobo, as mães-tigres e as leoas amamentam os cordeiros e os cabritos, o gato e o cão brincam na relva macia. Tudo é paz e alegria. Uma claridade maravilhosa banha todas as coisas... A noite não vem jamais mergulhar tudo nas suas trevas, e não sopram as borrascas que arrastam consigo as nuvens sombrias. Nós colhemos frutos suculentos de tamanhos jamais visto; saciamos nossa sede nos regatos de leite de límpidas fontes. (BRANDÃO, 1957, p. 206-7 apud RIBEIRO, 1986, p. 29).
\end{abstract}

É certo que a narrativa de São Brandão influenciou vários navegadores e aventureiros do século XV. Sérgio Buarque, em Visão do Paraíso, estudou como a metáfora do Éden repercutiu na época da colonização brasileira, observando como ela se figurou ao nosso passado e propriamente como se estabeleceu enquanto fundamentação da própria história do Brasil. Nesse sentido, como aponta a obra de Sérgio, o nosso país povoou o imaginário do colonizador através de um repertório de crenças e lendas que associavam o Brasil à ideia de um paraíso terrestre e longínquo, mas nem por isso fora do alcance efetivo dos homens. O historiador ainda cita trechos escritos por Cristóvão Colombo em que percebemos esta influência: "Creí [...] y creo aquello que creyeron y creen todos santos y sábios teólogos que alli, em la comarca, es el paraíso Terrenal." (apud HOLANDA, 2000, p. 238).

Desde o início da nossa colonização, o continente americano serviu a projeções utópicas do colonizador; motivadas pela exuberância de uma natureza em estado intocável. Uma destas projeções resulta das influências do famoso Mito do Eldorado sobre o imaginário do colonizador no momento da descoberta do Novo Mundo. Estas influências atestam uma série de imagens ideais da terra descoberta como se pode notar, por exemplo, na Carta de Caminha, na qual o escrivão da frota de Cabral exalta, de forma recorrente, a salubridade dos ares, a fertilidade do solo, a exuberância da vegetação e, através de comparações, associa o habitante da terra ao do paraíso. Além dos textos já citados, vários outros escritores do século XV celebraram o mito destas ilhas afortunadas: Camões, Cervantes, Montaigne, Ronsard, etc.; assim como são abundantes as referências nos textos dos cronistas e viajantes.

O mito da idade de ouro está presente em todos os lugares do mundo. Em geral, na variedade destes relatos, há alguns elementos sempre constantes, tanto os que se referem à mitologia cristã quanto à mitologia pagã. Em síntese, podemos dizer que a condição paradisíaca dessa mitologia se configura pela imortalidade, a liberdade total, a amizade entre o homem e a natureza, a felicidade plena, a colheita dos frutos da terra sem nenhum tipo de trabalho, etc. $O$ homem perde esta condição original por causa de um acontecimento primordial, a "Queda". Acontecimento que o torna mortal, sofredor, tem que conseguir sobreviver com o suor de seu trabalho como também sua comunicação com a natureza e com os deuses é interrompida. 
De acordo com Gilberto Mendonça Teles, é em Tempo e Eternidade, no poema "Distribuição da poesia", que aparece pela primeira vez a palavra ilha na poética de Jorge Lima, e é também neste momento que surgem os sinais de uma nova concepção poética em sua obra. A ilha passa a ser vista como o paraíso perdido, próximo de Deus e, portanto, próximo das origens, crescendo na obra do poeta até tornar-se tema central em Invenção de Orfeu.

\author{
A vida está malograda, \\ creio nas mágicas de Deus. \\ Os galos não cantam, \\ a manhã não raiou. \\ Vi os navios irem e voltarem. \\ Vi os infelizes irem e voltarem. \\ Vi os homens obesos dentro do fogo. \\ Vi ziguezagues na escuridão. \\ Capitão-mor, onde é o Congo? \\ Onde é a Ilha de São Brandão? \\ Capitão-mor que noite escura! \\ Uivam molossos na escuridão. \\ Ó indesejáveis, qual o país, \\ qual o país que desejas?
}

É sintomático o apelo que o poeta faz a Deus pelos oprimidos, como deixa evidente a referência aos escravos negros e ao homem em geral, que se encontram errantes e perdidos num mundo conturbado. É por isso que ele pergunta "Onde é a Ilha de São Brandão?", pois quer encontrar um lugar mítico e paradisíaco diferenciado do mundo que se depara. O poeta utiliza-se de uma linguagem mítica numa fusão do signo com objeto como se a palavra fosse o próprio ser, que será a linguagem bem característica de Invenção de Orfeu, numa tentativa de reordenar o mundo por meio da palavra poética. Assim, os versos seguintes: "A vida está malograda,/creio nas mágicas de Deus./Os galos não cantam,/a manhã não raiou." afirmam a força do verbo, pois sem ele (se os galos não cantarem) o amanhã não nascerá.

Em "Convite para Ilha", poema de A Túnica Inconsútil, vemos a configuração da ilha limiana estreitamente relacionada ao mito do paraíso terrestre, expressão de seu desejo de evasão do mundo real, uma espécie de refúgio na utopia de sua ilha. Essa ilha é configurada por um ambiente imaginativo, como se nota pela união de elementos contrastantes e estranhos uns aos outros como demonstram os seres pertencentes a reinos distintos unidos ou mesmo metamorfoseados: "peixe cantor", "boto voador"; como também pelo contraste de cores na composição: "baleias azuis" e o "ouriço vermelho", ou pelo próprio ambiente claramente paradisíaco no poema: "ilha mais bonita não há", "água morna", "rios de leite", "terras bulindo", etc. Desse modo, é perfeitamente visível a configuração do topos do paraíso; no entanto, este topos está configurado de um modo novo, retrabalhado e rearranjado por meio de uma escritura onírica em que não há a preocupação em configurar este mundo de maneira realista ou mimética. Há sim uma intenção de romper com esta forma de representação. 
Não digo em que signo se encontra esta ilha mas ilha mais bela não há no alto mar.

O peixe cantor existe por lá.

Ao norte dá tudo: baleias azuis, o ouriço vermelho, o bôto voador.

A leste da ilha há o Geyser gigante

deitando água morna. Quem quer se banhar?

Há plantas carnívoras sem gula que amam.

Ao sul o que há? - há rios de leite,

há terras bulindo, mulheres nascendo,

raízes subindo, lagunas tremendo,

coqueiros gemendo, areias se entreabrindo.

Em Anunciação e Encontro de Mira-Celi ${ }^{4}$, o poema "23" relaciona a figura de Mira-Celi ao mar como símbolo da fecundidade e da origem da vida em seu sentido primordial (de antes mesmo do nascimento), em um claro desejo de encontro com a origem e/ou a eternidade.

Uma das minhas solidões repousa no lácteo mar de seu ventre;

mas os olhos dos pastores e dos nautas

sempre se alimentam dela.

Na verdade é apenas uma constelação cristã

formada nos primeiros dias,

com a aparência de cisne, de chama ou de duna

em que se ostenta um de meus horizontes.

Ela aspira a vida eterna, meu Deus!

No Livro de Sonetos é grande a quantidade de poemas que nos remete ao tempo dos primórdios. A título de exemplo citamos apenas um, em que se revela a imaginação, a memória, a ilha e a associação da criação poética à criação divina.

Imaginai no firmamento de antes

dois nevoeiros em oito entrelaçados,

galo e penumbra, draga sempre em púbis

penetrada de proas dominantes.

E a calmaria toda havia há instantes

em círculo de sal e cios porfiados.

\footnotetext{
${ }^{4}$ Este Livro, singular em toda literatura brasileira, além de conter toda uma simbologia náutica e se caracterizar por seu hermetismo, nos revela muito do que virá adiante na poética de Jorge de Lima. É mesmo uma preparação anunciada para a elaboração de Invenção de Orfeu, que se torna evidente nos versos seguintes: "Os grandes poemas ainda permanecem inéditos" (poema "4"); "Os grandes poemas começam com a nossa visão desdobrada" (no poema "56"). Chama a atenção também seu caráter circular, no sentido de que seu primeiro e o último poema começam da mesma maneira como se um fosse continuidade do outro: "O inesperado ser começou a desenrolar as suas faixas em que/estava a história da criação passada e futura.". Esse aspecto demonstra o desejo, expresso nos dois poemas (Anunciação e encontro de MiraCeli e Invenção de Orfeu), do rompimento temporal e do encontro do poeta com a eternidade.
} 
Desde a baba dos cabos bojadores.

Sobre a ilha em vermelhos tão agudos.

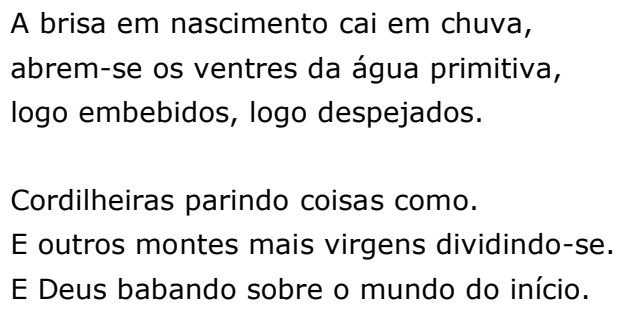

Em Invenção de Orfeu o vocábulo "ilha" é utilizado pelo poeta de maneira constante, pode ser lido primeiramente no sentido denotativo, de acidente geográfico, em sua referência histórica à Ilha de Santa Cruz; como imagem de Portugal, ilha dentro da Europa ou do próprio Brasil, ilha dentro da América Latina, "linguística, racial e social" (PICHIO, 1988, p. 90), passando pelas conotações de ilhas fabulosas na antiguidade e no período medieval e pelas idealizações utópicas dos filósofos renascentistas até chegar às conotações simbólicas do paraíso, lugar edênico, aproximando-se gradativamente da ideia de "lugar de poesia". (TELES, 1988, p. 135). A "ilha" recebe várias características ao longo de todo o poema, e se estrutura num terreno marcadamente literário, relacionando-se, mas também transcendendo, o significado de várias outras ilhas, como as de Dante, de John Milton, de Camões, da Bíblia e a de Thomas Morus.

Podemos dizer que Invenção de Orfeu se desenvolve em três tempos: o primeiro; é o momento da Criação, o Éden, a felicidade primitiva, real e sonhada; o segundo, refere-se ao instante da Queda, da perdição, do obscurecimento, destruição e morte; o terceiro, é aquele da salvação, redenção, em que poema e poeta se vitalizam na fé, na esperança e no amor.

É por meio desse "desenho" poético que o motivo do lócus amoenus será trabalhado. É exemplar a estância XXVIII, do Canto Primeiro, em que o poema assume uma dimensão histórica se relacionando diretamente à tradição literária portuguesa. No primeiro caso, nota-se uma relação estreita da famosa ilha de São Brandão ao Brasil, caracterizado como uma terra paradisíaca, já que mais adiante se associará com a Carta de Caminha, na qual é descrito como uma terra maravilhosa. A presença e nomeação de seus "descobridores" ou colonizadores garantem ainda dados históricos: Vasco da Gama, padre Jerônimo, D. José, Caminha e Perestrelo. No segundo caso, a tradição literária é percebida através de Camões, com a alusão ao gigante Adamastor e também com a sua musa maior Inês de Castro, e de Fernando Pessoa por meio do diálogo intertextual com Mensagem.

As raízes são minhas, pedra lusa e refrão de aventuras renovadas; eis esse itinerário de meus nomes, eis esse aço de afiar minhas espadas, penedo de esbarras naves absortas, febre dura de fé, vocabulário, ó meu pai Perestrelo, ó vós Jerônimo. 
Contemplo as rochas puras que assistiram

passar por essas tardes caravelas;

o sulco inda foi ontem, doce Olaia:

tu jazias nos Anjos, (coisa estranha!)

descobrimos nas ondas essas algas,

essas Índias tão nuas, esses ventos,

essas admirações em São Brandão!

E depois escrevemos uma carta

contando tuas graças, nessas praias,

sobre os giolhos das moças, nas vergonhas.

No entretanto ali estão as outras faces.

$\mathrm{Ah}$ ! as praias e as tragédias e as Ineses,

e os presságios bilíngues, multilíngues

e as visões tão fatais, tão desabridas.

Ó desaparecidos, ó encobertos,

ó perdidos nas guerras e nas coplas,

eu morro junto a vós, nesses rochedos

das certezas finais desencontradas,

reis desejados, sopros ocultados,

esperança e renúncia, ó $D$. José,

queridas confusões vos dou. (LIMA, 1958, p. 652)

Outro elemento presente no poema se refere às Índias e/ou índias. Estes vocábulos rapidamente nos remetem ao tempo do "descobrimento" do Brasil, seja no seu caráter literal (do índio habitante do Brasil em seus primórdios) ou pela própria associação errônea do Brasil às Índias (onde Portugal buscava suas especiarias). Mas o que se mostra mais significativo no poema é mesmo a caracterização da índia (mulher) e seu habitat, o que revela o próprio imaginário europeu de que a terra "descoberta" era um lugar aprazível e sensual, como um paraíso terreno. O que acrescenta ao mito do locus amoenus um elemento a mais, a sexualidade livre.

Na estância XXXI, do mesmo Canto, o processo de colonização portuguesa é novamente denunciado através da glosa feita a Carta de Caminha a Dom Manuel. Esse aspecto revela o claro desejo do poeta de retomar a origem brasileira concentrada na figura primordial do índio, como revela a representação do Brasil como uma terra excepcional, onde tudo dá, e como terra da inocência, nos remetendo ao paraíso bíblico onde Adão e Eva viviam nus sem nenhum constrangimento.

Esquecidos dos donos, nós os bastos, nós os complexos, nós os pioneiros, nós os devastadores e assassinos, vamos agora fabricar o índio com a tristeza da mata e a fuga da maloca, com a alegria de caçar. 
Vamos dar-Ihe paciência de amansar

os bichos, de juntar as belas penas,

raízes, frutos; vamos abalar

com ele o chão da maloca, batucando.

essa terra dançada, D. Manuel,

de ponta a ponta é toda de arvoredos.

É toda de arvoredos e de ar bom,

como o ar bom de Entre-Douro-e-Minho, e as águas

são muitas, infinitas, tudo dando,

dando peixe, lavando a carne nua,

lambendo os pés da selva embaraçosa,

a feição é ser parda, bons narizes.

Boas vergonhas nuas, boas caras

e bons Jeans de Lery contanto as coisas.

Ausentes recalques e pudores

e colares de dentes de contas

para atrair as musas e as mães-d'água,

e adornos para os sexos merecidos.

Nenhuma ideia exata possuímos

sobre origens de carnes e de sangues,

mas de mortes somente, mesmas caras

que vós, mesmos desejos, nós indígenas,

vós indígenas, nós madeiras mesmas,

decadentes, corroídas, não pacíficas. (LIMA, 1958, p. 656)

De acordo com Lúcia de Sá, Jorge de Lima faz uma importante modificação nos textos de viagens nessa estância no sentido de problematizar a sua "voz narrativa". Estes textos, na maioria das vezes narrados na primeira pessoa descrevem os índios sempre em terceira pessoa estabelecendo uma clara distinção entre o "eu/homem europeu" e "ele/indígenas" ${ }^{\prime \prime}$. Jorge de Lima, como vemos na última estrofe desse fragmento, apresenta os índios tanto na primeira quanto na segunda pessoa do plural, o que obriga o leitor a questionar sua identidade. Desse modo, temos em Invenção de Orfeu um questionamento dessas identidades, problematização que

vem acompanhando as representações culturais do indígena em nossa sociedade desde o indianismo romântico. Os índios foram identificados pelos escritores desse período como símbolo de um nós brasileiro que se compunha de um vós europeu. Mas os românticos foram acusados de estarem na verdade imitando os franceses, ou seja, de estarem agindo como um nós francês em relação a um vós brasileiro.

${ }^{5}$ Echeverría aponta que a miscigenação entre o índio e o português, como se pode ver na primeira estrofe deste trecho do poema, é mostrada "pela tensão presentificada (mítica e fantástica): compartilhada pelo emissor e os receptores através do pronome em primeira pessoa do plural (nós)." Transgressão que permite conjugar "o 'eu' (o Mesmo) e os receptores (o Outro). Mediante o espelho discursivo (Kristeva), o enunciado fica aquém do verossímil." Para a ensaísta, este "processo mítico e fantástico de 'fabricar o índio', na práxis, amplifica o histórico, a conjugação dos sememas opostos, que recuperam imageticamente a visão crítica dos brasileiros e do país. Repensando-se a origem, unifica-se o discurso." (ECHEVERRÍA, 1978, p. 33). 
Essa questão foi retomada no modernismo em tons semelhantes, a não ser pelo fato de o nós indígena dos modernistas incluir, através da antropofagia, o vós europeu, e ter frequentemente em relação ao nós do movimento um distanciamento criado pela paródia, embora os modernistas fossem também acusados de serem um vós europeu travestido de nós brasileiro. (SÁ, 2000, p. 7).

Na sequência dessa estância temos a figura do índio associada não apenas ao habitante do Brasil, mas ao homem primitivo. O que nos leva a crer que o sentido primeiro (o índio brasileiro) é transfigurado numa imagem simbólica universal (do homem primitivo, primeiro); afinal as Índias são abrangentes "ocidental" e "oriental". Nesse sentido, temos em Invenção de Orfeu o caráter local ampliado para uma concepção universal e arquetípica em sua poesia revelada, justamente pela associação do índio ao homem anterior à queda do paraíso.

Goiazis, matuins, encantada Índia, sempre Índia ocidental, oriental Índia, povoada de cardumes mitológicos, minhas proas cortando tenebrosos mares, de duendes lusos e outras nuvens, promotórios, gigantes e grandezas. (LIMA, 1958, p. 657)

Ainda, sequencialmente, nesta mesma estância, vemos novamente a associação do mundo do índio ao princípio dos tempos anterior à Queda. Nesse mundo primordial, intocado pela civilização, onde não há guerras e há harmonia do homem com a natureza, é que o poeta busca a linguagem de seu poema, a linguagem que se falava no Brasil pelos índios em seus primórdios, a linguagem dos bororos. Desse modo, o desejo de volta ao primitivo pode significar metaforicamente que o poeta está em busca da origem do homem e da poesia do tempo primordial. É o que explicita a língua do índio expressa no poema. O que pode também revelar um possível projeto de resgate e ou de criação de uma suposta língua nacional associada ao verbo primordial. Assim, "Invenção de Orfeu oferece o retrato do solo e gente do Brasil. Retrato de nossa idealidade, tanto quanto o é de nossa realidade; e retrato de nossas utopias." (MOISÉS, 1989, p. 145).

E eu menino pequeno, todo penas, com essas flechas sem leis e esses colares prefaciando viagens, aventuras, narradores de pêtas européias, eu sem ouros, com apenas maracás, bondades naturais, recém nascidas.

Eu índio indiferente, mau selvagem, bom selvagem nascido pra o humanismo, à lei da natureza me despindo com pilotos e epístolas, cabrais, navegações e viagens e ramúsios, santa-cruzes, vespúcios, pau-brasis. 
E eu palavreando com esses papagaios

completamente apócrifo no mundo,

cosmogonia nua, áspero clima

sem moeda e comércio, muito bem,

liberdade social, perfeitamente

com tacapes ferindo mas sem guerras.

Sobretudo eu escravo do homem branco,

ó cunhãs, inocências e pobrezas,

curiosidades sobre meus amores,

visões de missionários, flor de peles,

narrativas de naus e manuscritos,

madeiras de Colombos e de Espanhas.

Vivo estranho em Lisboa babeladas

entre chins e japões pelas ruelas,

os domínios distantes me afogando,

cotovelando pelo Rei das quinas,

resgatado com fardos e tonéis,

descoberto de trajes e de galas.

Ou então em bororo me chamando.

_ Que venha o peixe açougue! E o peixe veio

E outros peixes gerados com ixegui.

Quero dois paus para acender meu fogo,

a morada das almas me chamou,

bororo forte, linguagem de bororo. (LIMA, 1958, p. 657)

A presença do índio e de sua cultura em Invenção de Orfeu coloca Jorge de Lima dentro da tradição indianista da literatura brasileira, que inicialmente se manifestou através das cartas dos navegantes portugueses que tinham o simples objetivo de informação (mesmo que fossem fantasiosas). Posteriormente essa figuração do indígena se dá por meio do indianismo romântico idealizado por José de Alencar, Gonçalves Dias, entre outros. Mais tarde, ocorre o indianismo antropófago, manifestação do modernismo cunhado por Oswald de Andrade. Jorge de Lima se associa a essas diversas referências e ao movimento modernista em seu ensaio "Todos cantam a sua terra", ressaltando o caráter de mistura de culturas (textos) com o intuito de criar uma literatura própria, genuinamente brasileira.

Além de criticar a exploração sofrida pelos índios, na sequência desta estância vemos claramente a relação estabelecida pelo poeta entre a utopia e o índio, através da contraposição entre os mundos "civilizado" e "bárbaro", privilegiando o mundo do índio. Mesmo assim, a ironia não deixa de estar presente a partir de uma síntese de elementos associados à imagem do índio que vão desde a caracterização idealizada do índio por Rousseau, passando por Montaigne e o índio considerado um "Adão perfeito" (o que novamente nos remete ao desejo do poeta criar seu poema por meio da inocência de antes da perda do Paraíso), para em seguida aportar em Gonçalves Dias, considerado o poeta dos índios, e Thomas Morus, "inventor de índios". Assim, o fazer 
poético está ligado à renovação da palavra poética como Verbo em seu sentido divino. A criação do novo mundo se dá a partir da negação do caos da história humana. Nesse sentido, a poesia se dá como uma busca da redenção, a fim de conseguir novamente seu estado anterior à Queda, ou seja o paraíso. A poesia é o instrumento restaurador de uma nova verdade que o mundo tanto necessita.

Comer, nós não comemos nenhum bispo, o branco mente muito, o corrompido, embaraça essa vida, o branco é assim. Comer nós não comemos nenhum branco, nem fumamos mentiras, fumo nosso, fumo de paz ou guerra, mas valente.

\section{$[\ldots]$}

Cravado de premissas e de olhares, de holofotes e cisnes, eis teu índio, grudado de tucanos e de araras, operário sem lei e sem Rousseau, incluído em dicionário filosófico, metáfora, gravura, ópera, símbolo. Utopia de santo e de sem - Deus, teu índio, teu avô, teu deserdado adão, perfeito Adão sem teus pudores falsos, consciências, dúvidas, receios, Emílio bronco, pai de Rousseu?

De que Montaigne? De que outra convivência?

Índios que te contém como moldura guardando personagens obrigadas, umas em redes, outras em gavetas, em redomas de prata, umas vestidas, outras despidas, umas tantas mortas, retratos desbotados, faces idas.

[...]

E esse grande Gonçalves, vosso neto desapartado aos cinco, da mãe parda, pra rouxinóis, choupais, capas, mondegos; e a colina coimbrã e as travessias, e o pão do exílio sem sabiás timbiras, e Ana Amélia, meu Deus, tão impossível.

$[\ldots]$

Quem vos mandou inventar índios... Morus, ilhas escritas, Morus, utopias, Morus, revoluções, Morus, ó Morus? Os índios se esconderam no homem branco, nos seus assombros, ele se invadindo de ocasionados índios, de outros índios. (LIMA, 1958, p. 659) 
É bom frisar, segundo as considerações feitas por Luiz Busatto (1989, p. 59-60), que a obra de Jorge de Lima a partir de 1942 sofreu grande influência do livro de Afonso Arinos de Melo Franco denominado $O$ índio brasileiro e Revolução Francesa ${ }^{6}$. De acordo com o crítico, Jorge de Lima teria ficado impressionado com este livro, pois nele Afonso Arinos explica que as ideias da Revolução Francesa e as ideias apresentadas por Rousseau em Emílio são matéria prima originalmente brasileira reelaborada. É por isso que no poema o índio brasileiro aparece como predecessor a Emílio: "Emílio bronco, pai de Rousseau?".

Ainda de acordo com Busatto, outros livros de literatura indígena também serviram de fontes para Jorge de Lima escrever Invenção de Orfeu. São eles: A Carta de Pero Vaz de Caminha, a Carta do Piloto Anônimo, o livro de André Thevet, $A$ singularidade da França Antártica; o livro de Jean de Léry, História de uma vigem à Terra do Brasil e outros, entre eles o seu próprio ensaio sobre Anchieta (1934).

\begin{abstract}
Esses livros de literatura indígena (excluído o ensaio de Jorge de Lima, é claro) determinam o pensamento de Jean-Jaques Rousseau e, portanto, influenciaram a Revolução Francesa. Afonso Arinos acaba por afirmar, no final do seu livro, sem receio, de que o maior colaborador na criação do mito do "bom selvagem" entrou nesta utopia intelectual levado pela mão do nosso índio. Então inverte-se totalmente a pedagogia de Rousseau. As ideias da Revolução Francesa que vieram ao Brasil não são ideias estrangeiras, mas apenas ideias brasileiras que retornaram ao país. Ora, se isso não é nacionalismo, então não existe nacionalismo no Brasil. (BUSATTO, 1988, p. 59-60).
\end{abstract}

Juntamente a essa relação de influência invertida o poema mostra o índio espoliado, desmoralizado, corrompido e doente, denunciando a influência maléfica do colonizador:

Já não estais, timbiras, já não sois.

É preciso andar sertões pra encontrar-vos, verter íntimos sangues, correr matos, braúnas, umbuzais para encontrar-vos. Já não sois belos como nos Caminhas, e sois enfermos e não sois tão nus.

Viveis presos, timbiras, nessas selvas selvagens, das memórias recalcadas, reclusos em varizes de libidos.

Nós choramos, timbiras, nós covardes, sofrendo os nossos dentes em nós mesmos.

\footnotetext{
${ }^{6}$ De acordo com Busatto, Jorge de Lima ao se encontrar com Afonso Arinos declarou que Invenção de Orfeu teria sido inspirado pelo seu livro $O$ índio e a Revolução Francesa. E "foi tão grande a admiração, que ele recomendou o livro a todos os seus alunos na Faculdade [que lecionava] e escreveu um artigo no jornal A Manhã de 19 de março de 1942. O artigo se chama "O índio Brasileiro" e não poupa elogio ao livro: "Um dos mais sérios, mais bem escritos, mais meditativos de toda a literatura brasileira é sem dúvida o livro de Afonso Arinos $O$ índio Brasileiro e a Revolução Francesa." (BUSATTO, 1988, p. 60).
} 
Moquém ruim, de carnes embricadas,

corrompido de terra e morticínios,

de aguardente, varíolas, vícios brancos

nós nascidos libertos, nós cativos,

dissolvidos nos sangues de outras gentes. (LIMA, 1958, p. 664)

Desse modo, o índio se configura em Invenção de Orfeu numa ampla gama de significações: ele é fruto da imaginação dos europeus, herói romântico idealizado, símbolo do homem natural, um "novo adão", sensual e também degradado e, nesse sentido, pode ser visto como um símbolo de resistência à empresa colonialista que o degradou e o humilhou como demonstra a permanência de seus traços culturais, seja através da sua própria língua e de alguns de seus costumes, seja por meio de sua própria existência nas regiões distantes do Brasil.

Todas estas considerações também apontam para uma característica que está sempre presente em Invenção de Orfeu e que pode ser relacionada às tentativas do Romantismo e até mesmo do Modernismo brasileiros de construção de um projeto de uma literatura nacional no sentido de que os escritores desse momento histórico desejavam alcançar uma expressão artística genuinamente brasileira, elaborada por suas variadas expressões culturais (do índio, do negro e do europeu), de suas paisagens características (não só a natureza exuberante mais também a geografia pobre do Nordeste brasileiro), da religião (sincrética: o catolicismo somado a expressão religiosa e ritualística tanto do negro quanto do índio), a busca de uma suposta língua nacional (composta pela mistura de léxicos do índio, do negro e do europeu) e também com a ruptura da imitação do modelo europeu que, no caso específico de Jorge de Lima, em Invenção de Orfeu, se configura na ruptura do modelo da epopeia clássica transfigurando-a num possível projeto épico-lírico. Desse modo, como já apontaram vários críticos, Invenção de Orfeu seria um poema genuinamente brasileiro ${ }^{7}$.

Ao ser questionado sobre o local onde decorre Invenção de Orfeu, Jorge de Lima responde:

Numa Ilha ideal-real, porque não existe geograficamente (toda a geografia do poema é inespacial), mas real, porque ao contrário da de Thomas Morus, onde os seres são perfeitos, nesta há miséria, sofrimentos, guerras. É uma ilha que tem um subsolo e um supersolo. O poema abrange o cotidiano, o natural, o prenatural o sobrenatural e o angélico. (LIMA, 1958, p. 93).

\footnotetext{
7 São exemplares as considerações do poeta, a esse respeito, em seu ensaio intitulado "Todos cantam sua terra" onde ele afirma: "Houve de fato ausência de Brasil nos antigos, hoje parece que há Brasil de propósito nos modernos. Porque nós não poderíamos com sinceridade achar Brasil no índio que Alencar isolou do negro, cedendo-lhe as qualidades lusas, batalhando por um abolicionismo literário do índio que nos dá a impressão de que o escravo daqueles tempos não era o preto, era o autóctone. 0 mesmo se deu com Gonçalves Dias em que o índio entrou com o vestuário de penas pequeno e escasso demais para disfarçar o que havia de Herculano no escritor. Os seus versos mais brasileiros e mais populares como "Minha terra tem palmeiras/onde canta o sabiá" nos dão a impressão inversa da desejada pelo poeta: que ele cantando os sabiás não se esquecera de Coimbra. Não havia realidade nessa literatura. Como não havia no negro de Castro Alves elevado a espártaco e servindo do pior romantismo do mundo que foi o de Hugo." (LIMA, 1958, p. 1015).
} 
Desse modo, não é impróprio considerar que a Ilha possa significar uma imagem fundamental, que conduz a estruturação do poema em relação à busca empreendida pelo poeta, de encontrar a eternidade perdida com a queda do homem no paraíso. São exemplares as epígrafes bíblicas dadas ao poema: "E, quando a casa se edificava, faziam-na de pedras lavradas e perfeitas; e não se ouviu martelo, nem machada, nem instrumento algum de ferro, enquanto ela se edificava." (III Reis, 7), simbolizando a imensidão espacial que ele ocupa, como também o caráter maravilhoso de sua construção, o que nos remete a um tempo mítico em que a criação acontece de forma espontânea. Assim também aponta a epígrafe retirada de Isaías 42,10: "Eu anuncio coisas novas, ilhas cantai um canto novo." Utilizando-se das palavras do Profeta para vislumbrar uma vida feliz, o poeta convida as ilhas a cantarem um canto novo, evidenciando, desde já, antes mesmo de iniciar o seu poema, sua associação ao profeta. De maneira geral, no sentido religioso, a expressão "ilha" sempre nos remete a lugares distantes que devem ser "evangelizados" ou precisam conhecer a palavra de Deus, podendo significar, também, a imagem do homem mesmo, num sentido metonímico (o lugar pelo habitante). Em muitos momentos esta imagem bíblica será referida, em Invenção de Orfeu, principalmente no que diz respeito ao desejo do poeta em encontrar a harmonia perdida e na busca da confraternização entre os homens. Ao lado da citação bíblica, aparece o texto de Apollinaire: "IL Y A". Este texto descreve basicamente a comunhão entre pessoas que vivem felizes e em harmonia com a natureza; seu título inegavelmente revela, a partir de sua sonoridade, a semelhança com a palavra portuguesa: Ilha.

A ilha, como figura central, no poema de Jorge de Lima será múltipla e receberá uma variada significação. Mas, é bom enfatizar que nas múltiplas significações da ilha se destaca o desejo do poeta de encontrar a união entre os homens para que possa haver uma futura comunhão universal. Seu desejo é, pois, reconquistar o paraíso perdido através do natural, do sobrenatural, de Deus e na soma de todos os tempos (passado, presente e futuro).

Invenção de Orfeu inicia-se mesmo com o canto denominado "Fundação da Ilha", e o termo "fundação" é bem sugestivo já que denota o estabelecimento dos alicerces para a edificação de seu poema. Portanto, o que o poeta pretende é estabelecer a base de seu poema (o que sustenta e possibilita qualquer edificação). Trata-se da busca de um mundo utópico, mas de uma utopia diversa de seu sentido original; no poeta brasileiro, a busca da perfeição poética se dá no movimento (tanto no que diz respeito à forma quanto ao conteúdo), contrariando a perfeição imóvel da ilha de Thomas Morus. É a busca do "Paraíso perdido" ou da origem associada à função utópica da literatura de mudar o mundo, através de sua recriação verbal, da transcendência e do imaginário.

É exemplar a estância I do Canto Primeiro, onde se estabelece uma importante proposição do poema em que o poeta nos apresenta seu herói, seu roteiro e seus objetivos, e nos diz qual é a ilha buscada por ele, uma ilha utópica. Etimologicamente, a palavra utopia recebe o significado de não-lugar (está fora do tempo e do espaço). A ilha buscada pelo poeta é também caracterizada de forma semelhante à utopia, pois 
ela é "de aquém e de além-mar", portanto não está em um lugar determinado, não sendo possível localizá-la, como revelam os termos assinalados: aquém (prep. e adv. do lado de cá de; inferiormente; abaixo; menos [antôn.:além]) e além (adv. Acolá; mais adiante; mais longe [antôn.: aquém.] - s.m. lugar distante; outras terras; lugar fronteiro a outro - elemento de composição de palavras com o sentido de "além de": além-mar; além-túmulo. Dicionário). Desse modo, a ilha limiana pode ser entendida como utópica, pois ela situa-se em um lugar que não existe, reportando-nos para uma realidade irreal. É interessante notar que além da ilha não ter uma localização específica, ela é caracterizada por uma contradição ou pelo menos por um paradoxo, que é revelado por sua (não)-determinação por meio de palavras antônimas, trazendo-Ihe ainda mais obscuridade. A ilha também pode ser considerada total mesmo não recebendo nenhuma localização; afinal, pode-se entender que ela ocupa um espaço que vai de aquém até além mar. Significado este que reforça ainda mais seu caráter utópico. O seu significado final a associa à busca e ao maior símbolo da fraternidade, o amor, como sugere a primeira estrofe, paródia do épico de Camões ${ }^{8}$.

Esta localização indefinida da ilha nos remete também a um tempo original, associado à busca de um espaço sagrado também sem limites e, portanto, primordial. No tempo primordial dá-se a união entre: passado, presente e futuro, caracterizando a celebração de um tempo mítico que contém a vida humana em sua totalidade. Nesse sentido, o passado se torna arquetípico, isto é, um passado que é potencialmente um futuro aparelhado para se encontrar com presente. Desse modo, o herói dessa pretendida epopeia buscará conquistar o espaço primordial através da memória. Este aspecto da simultaneidade presente na poética moderna nos remete ao desejo do poeta desse tempo querer reduzir distâncias através da possibilidade da aproximação espacial-temporal feita, muitas vezes, por suas metáforas, que associam termos dissonantes, e também pelo seu desejo de evasão do mundo em que vive. Esta comunhão entre os três tempos representa uma simultaneidade almejada pela poesia no intuito de eliminar os limites temporais como vemos explicito na viagem empreendida pelo herói limiano.

\footnotetext{
${ }^{8}$ É interessante expormos a concepção do lugar e o poder mágico da poesia concebido por Casais Monteiro, remetendo-nos ao caráter metalinguístico do poema de Jorge de Lima. Assim diz o crítico: "Mas, de fato, embora sem tornarmos num sentido demasiado técnico, como não reconhecer como fonte da poesia uma zona que se encontra aquém - ou além - da coincidência superficial do homem com sua vida cotidiana? Como ignorar que o valor das palavras ganha, na poesia, um poder de comunicação que seria absurdo se através da linguagem não se estabelecesse qualquer entendimento do homem para o homem, e do homem para as coisas, que não existe nas palavras quando tomadas unicamente como sinais? É certo que, tal como a linguagem da razão, a poesia também procura uma verdade. Mas é uma verdade daquela dimensão humana em que dois mais dois não é igual a quatro. Nem por isso é uma linguagem do absurdo, muito menos do irreal. O mais estranho poder da poesia é que torna o mundo mais verdadeiro, exatamente porque, nela, as palavras não funcionam como sinais, ou como rótulos, mas como substitutos de alguma coisa que permanece por trás delas. Todas as afinidades que têm sido postas entre a poesia e as mais diversas formas do ocultismo, resultam exatamente de ser a poesia uma operação mágica, de não poder deixar de se reconhecer na transfiguração da palavra que se opera na poesia, qualquer forma de alquimia, uma transformação do mais vil no mais nobre metal." (MONTEIRO, 1965, p. 31).
} 


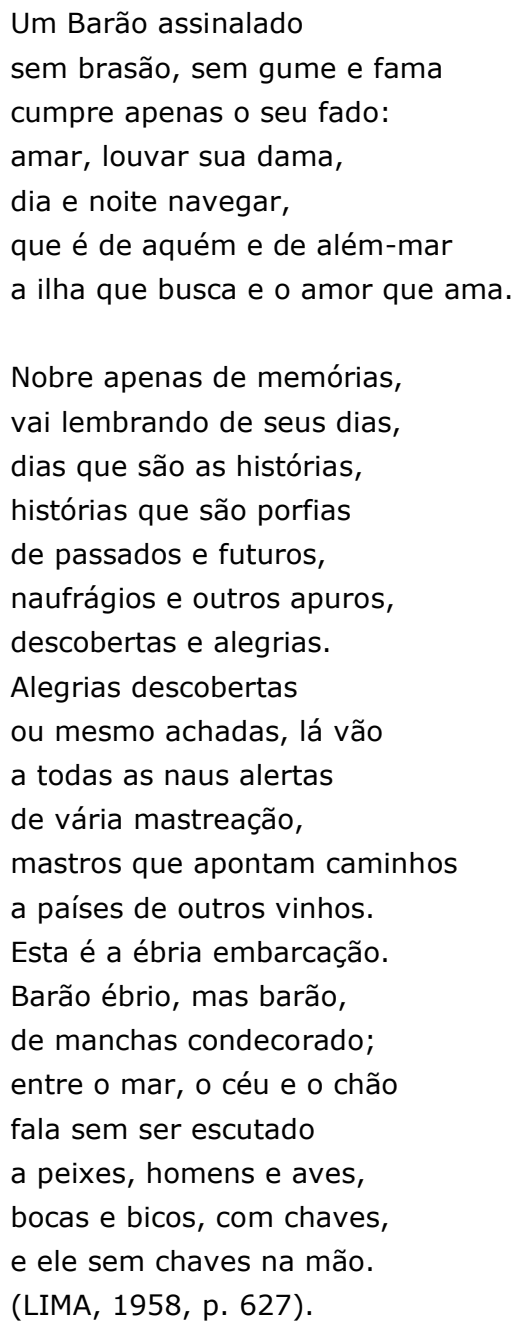

Nesse sentido, Invenção de Orfeu apresenta, já no seu início, pelo menos três das temáticas mais importantes e constantes do poema: a do herói (representado pelo próprio poeta que cumpre uma missão - Barão ébrio -, o que Ihe dá um caráter cristão por estar sujeito à vontade de Deus); a da viagem (que pode representar tanto a própria vida do homem, que metaforicamente "viaja" de seu nascimento até a morte, como também de uma viagem apenas imaginária e metalinguística) e a da ilha (que é a meta do herói e, como acreditamos, pode representar a metáfora central do poema).

Comecemos por delinear alguns elementos importantes presentes nesta estância. Primeiramente, encontramos a figura do Barão (como é caracterizado o herói do poema), que carrega, originalmente, o sentido de nobreza, conduzindo-nos a uma imagem característica do herói marcado por atitudes de coragem e de grandes feitos, remetendo-se diretamente ao herói camoniano d'Os Lusíadas. A relação deste ao herói limiano, no entanto, é em seguida desmistificada a partir de sua caracterização como "ébrio", que imediatamente o associa à tradição poética da modernidade (Rimbaud - $O$ barco bêbado). Posteriormente, encontramos um elemento que se mostra de grande 
importância para todo o poema, uma "chave" ${ }^{\prime \prime}$, pois ela simboliza uma espécie de artefato capaz de restaurar a harmonia perdida pelo homem com a Queda. É a busca deste artefato e/ou da reconquista da perfeição que sustenta a aventura do heróipoeta em sua pretendida epopeia. Esta busca mítica fundamental da humanidade e suas referências intertextuais às epopeias clássicas também nos remetem ao poder revelador da palavra poética. Nesse sentido, a reconquista do paraíso perdido se dá através da palavra, da poesia. $E$, desse modo, outro elemento importante no poema de Jorge de Lima se apresenta nesta estância, Orfeu. Herói de seu poema que se confunde com o próprio poeta e seu ofício, ele é a figura que orienta a busca da harmonia perdida. Portanto, a chave buscada está dentro do próprio herói, é a própria poesia ou a palavra poética.

É em busca desse tempo inicial que ocorre o rompimento com o fluxo temporal histórico no poema, revelando-nos um tempo predominantemente interior. Desse modo, Invenção de Orfeu se relaciona diretamente a um passado mítico numa tentativa de busca de uma "criação primeira" associada ao tempo inicial paradisíaco, antes mesmo da contagem do tempo empírico. É nesse sentido, da busca de um tempo mítico, que o poema se direciona para uma época das "ações primeiras" e por isso mesmo modelar, como também revela seu receptáculo de forças mágicas e espirituais. Portanto, a origem e/ou o passado mítico se mostram como o lugar da sabedoria e da essência das coisas.

\section{Referências}

BUSATTO, Luiz. Montagem em Invenção de Orfeu. Rio de Janeiro: Âmbito Cultural, 1978.

CURTIUS, Ernest Robert. Literatura Européia e Idade Média Latina. Trad. de

Teodoro Cabral e Paulo Rónai. São Paulo: Hucitec;Edusp, 1996.

ECHEVERRÍA, Lídia Neghme. Algumas orientações poéticas em Invenção de Orfeu.

Colóquio/Letras, n. 41, jan. 1978.

HESÍODO. Teogonia - a origem dos deuses. Est. e trad. de Jaa Torrano. São Paulo: Iluminuras, 1995.

HESÍODO. Os trabalhos e os dias. Primeira parte: Introd., Trad. e coment. de Mary Neves Lafer. São Paulo: Iluminuras, 1996.

HOLANDA, Sérgio. Visão do paraíso: os motivos edênicos no descobrimento e colonização do Brasil. São Paulo: Brasiliense; Publifolha. 2000.

\footnotetext{
9 Em suas "Memórias", o poeta se refere a uma chave que marcou suas lembranças. Isso pode significar que realmente Jorge de Lima está em busca desse momento, do retorno à infância perdida. Nesse sentido, a viagem empreendida pelo nauta-poeta em Invenção de Orfeu representaria a tentativa de reconquistar esse tempo paradisíaco da infância: "Lembrança da Casa-grande tenho muita que depois tratarei, como por exemplo da sala das chaves, chaves enormes de ferro penduradas a seus ganchos: trinta com os destinos, do paiol, do escritório, da despensa, da capela, capela de Santana onde havia missal no altar-mor e sacristia com gavetões de jacarandá." (LIMA, 1958, p. 99).
} 
LIMA Jorge de. Obra Completa. Org. de Afrânio Coutinho. Rio de Janeiro: Aguilar, 1958.

MOISÉS, Massaud. Jorge de Lima. In: História da Literatura Brasileira: modernismo. 3 ed. São Paulo: Cultrix, 1983-1989.

MONTEIRO, Adolfo Casais. A palavra essencial: estudos sobre a poesia. São Paulo: Cia. Editora Nacional/EDUSP, 1965.

OVÍDIO. As metamorfoses. Trad. de Bocage. São Paulo: Hedra, 2000.

PICCHIO, Luciana Stengagno. O Poeta e sua dimensão universal. In: RÈBAUD, JeanPaul (org.) 90 anos de Jorge de Lima (Anais do Segundo Simpósio de Literatura Alagoano). Maceió: UFAL, 1988.

RIBEIRO, Lêda Tâmega. O mito da Idade do Ouro. In: Mito e poesia popular. Rio de Janeiro: FUNARTE/Instituto Nacional do Folclore, 1986.

SÁ, Lúcia. Invenção de Orfeu e o palimpsesto indígena. Luso-Brazilian Review, University of Wisconsin at Madison, v. 37, n. 1, Summer, 2000.

TELES, Gilberto Mendonça. Jorge de Lima e a geração de 1893. In: RÈBAUD, Jean-Paul (org.) 90 anos de Jorge de Lima (Anais do Segundo Simpósio de Literatura Alagoano). Maceió: UFAL, 1988.

VIRGÍLIO. Bucólicas. Trad. de Péricles da Silva Ramos. São Paulo: Melhoramentos; Brasília: Ed. Universidade de Brasília, 1982.

\section{Title}

Invenção de Orfeu, Jorge de Lima in search of the age of gold

\section{Abstract}

This text intends to examine as Jorge de Lima in Invenção de Orfeu, in a mythical-poetical onslaught, searchs to restore the age of gold in its poem. In this direction, we will study exemplary authors of the literary tradition occidental person who had worked this subject, establishing a possible dialogue of the poet alagoano with this tradition.

\section{Keywords}

Invenção de Orfeu. Myth. Poetry. Age of gold.

Recebido em 10/04/2012. Aprovado em 5/11/2012. 